\title{
FAKTOR PENYEBAB KESULITAN BELAJAR MATEMATIKA PADA SISWA KELAS IV DI SDN JAWA 2 MARTAPURA KABUPATEN BANJAR
}

\author{
Noor Fazariah Handayani, Mahrita \\ Program Studi Pendidikan Guru Sekolah Dasar; Bimbingan Konseling \\ Universitas Achmad Yani Banjarmasin \\ Email: noorfazariah@uay.ac.id; mahrita@uay.ac.id
}

Website : https://jurnal.uin-antasari.ac.id/index.php/ptkpend/index

Received: 17 Oktober 2020; Accepted: 29 Desember 2020; Published: 1 Januari 2021

\begin{abstract}
This Research was aimed to known the factors causing the difficulty of learning mathematics in class IV students at the Java 2 Martapura Elementary School, Banjar Regency. The research subjects were students of SDN Jawa 2 Martapura, Banjar Regency. The data collection technique was taken through a questionnaire and observation. The results of the study show that from internal factors, many (66\%) students said they never had the will to do Maths problems, quite a lot (46.33\%) students said they were never happy with Mathematics learning, a lot (90\%) students said they always difficulties with learning Mathematics, quite a lot $(49.33 \%)$ of students said they had never been interested in learning Mathematics, a few (40\%) students said they were sometimes ready to participate in Mathematics learning Meanwhile, seen from external factors, quite a lot $(48.66 \%)$ of students said they were never happy with the teaching method of teachers in class, a little (37.66\%) students said that sometimes Mathematics teachers used the learning method, quite a lot ( $48 \%$ ) students said they had never had a satisfactory Mathematics learning facility, many (63.5\%) students said they were always happy with the quiet class conditions. So it is suggested to all schools to continue to improve techniques and creativity in teaching, and to continue to provide guidance and motivation to students in teaching.
\end{abstract}

Key Words: Causes of Difficulty; Mathematics Lessons

\section{ABSTRAK}

Penelitian ini bertujuan untuk mengetahui faktor penyebab kesulitan belajar matematika pada siswa kela IV di Sekolah Dasar Negeri Jawa 2 Martapura Kabupaten Banjar. Subjek penelitian siswa dan siswi SDN Jawa 2 Martapura Kabupaten Banjar. Teknik pengumpulan data diambil melalui angket, dan observasi. Hasil penelitian menunujukan bahwa dari faktor internal, banyak (66\%) siswa mengatakan tidak pernah mempunyai kemauan dalam mengerjakan soal Matematika, cukup banyak (46,33\%) siswa mengatakan tidak pernah senang terhadap pembelajaran Matematika, banyak sekali (90\%) siswa mengatakan selalu kesulitan terhadap pembelajaran Matematika, cukup banyak $(49,33 \%)$ siswa mengatakan tidak pernah minat terhadap pembelajaran Matematika, sedikit (40\%) siswa mengatakan kadang-kadang siap mengikuti dalam pembelajaran Matematika. Sedangkan dilihat dari faktor eksternal, cukup banyak $(48,66 \%)$ siswa mengatakan tidak pernah senang terhadap cara mengajar Guru di kelas, sedikit $(37,66 \%)$ siswa mengatakan kadang-kadang saja Guru mata pelajaran Matematika menggunakan metode pembelajaran, cukup banyak (48\%) siswa mengatakan tidak pernah mendapatkan sarana pembelajaran Matematika yang 
memuaskan, banyak $(63,5 \%)$ siswa yang mengatakan selalu senang terhadap kondisi kelas yang tenang. Sehingga disarankan kepada semua pihak sekolah agar terus meningkatkan teknik dan kreativitas dalam mengajar, serta terus memberikan bimbingan dan motivasi para siswa dalam mengajar.

Kata Kunci: Penyebab Kesulitan; Pelajaran Matematika

\section{PENDAHULUAN}

Pendidikan adalah kegiatan belajar mengajar, membimbing, dan mendidik, peserta didik agar mempunyai bekal dasar berupa pembentukan sikap, pengetahuan, dan keterampilan kerja. Ini menunjukkan bahwa pendidikan menjadi kebutuhan pokok dalam kehidupan manusia. Tujuan pendidikan tidak dapat dikatakan sukses tanpa usaha guru dalam mengelola pembelajaran adalah menciptakan situasi dan kondisi yang memungkinkan siswa berhasil belajar berdaya guna hingga tercipta SDM cerdas yang mampu berkompetisi di era globalisasi.

Matematika merupakan pelajaran menyenangkan karena melatih ketelitian, berpikir kritis dan praktis, namun masih ada yang merasa Matematika itu sulit dan menegangkan, sehingga kurang diminati oleh siswa. Materi dan kegunaan matematika telah berkembang pesat karena berfungsi melambangkan kompetensi komunikasi dengan mewujudkan bilangan-bilangan dan simbol-simbol yang dapat memberi kejelasan serta penyelesaian permasalahan dalam kehidupan sehari-hari.

Dalam proses pembelajaran, metode ceramah monoton masih digunakan sebagian guru tanpa keterlibatan siswa sehingga membuat pembelajaran tidak efektif dan kurang menyenangkan, kemampuan kerjasama, berpikir kritis dan sikap sosial siswa tidak tercapai. Tugas utama guru adalah membelajarkan siswa. Belajar merupakan proses perubahan perilaku.

Metode pembelajaran bervariasi dapat menjadikan situasi proses pembelajaran di sekolah sebagai kegiatan menjadikan siswa lebih aktif dan mampu memecahkan masalah sendiri dibawah pengawasan dan bimbingan guru. Pemilihan metode dilakukan melalui kerjasama yang aktif dan kreatif antara guru dan siswa. Selain penggunaan metode pembelajaran bervariasi, guru juga harus memperhatikan kesiapan menerima pelajaran dan minat belajar siswa dengan nyaman sehingga dapat menerima hasil pelajaran dengan baik. Minat berpengaruh besar terhadap proses pembelajaran.

Penelitian Andri, dkk (2020) memperlihatkan Hasil analisis faktor ditemukan 5 faktor yang mengelompok yang mempengaruhi kesulitan belajar yang diberi nama faktor minat dengan persentase variance $28.997 \%$, faktor guru dengan persentase $14.386 \%$, faktor kebiasaan belajar dengan persentase $9.860 \%$, faktor lingkungan keluarga dengan persentase $9.860 \%$ dan faktor suasana rumah dengan persentase varians 7.290\%. Sedangkan faktor yang paling dominan mempengaruhi kesulitan belajar yaitu faktor minat dengan persentase varians $28,997 \%$

Berdasarkan hasil observasi peneliti di SDN Jawa 2 Martapura, Komplek Pangeran Antasari Martapura Banjar Kalimantan Selatan, terdapat siswa yang masih kurang minat belajar di sekolah terutama pelajaran Matematika. Kebanyakan siswa berpendapat bahwa pelajaran Matematika sangatlah sulit untuk mereka pahami dibandingkan dengan mata pelajaran lainnya. Sebagian guru masih menggunakan metode ceramah dan penugasan tanpa memperhatikan siswa apakah sudah benar-benar mengerti atau belum, menjadikan proses pembelajaran tidak efektif dan kurang dinikmati, sehingga respon siswa kurang serta konsep pelajaran yang disampaikan sulit dipahami mengakibatkan prestasi belajar 
Matematika mereka menjadi turun dan rendah. Padahal Matematika merupakan salah satu mata pelajaran yang sangat penting didalam kurikulum pembelajaran.

Berdasarkan uraian di atas dilakukan penelitian mengenai "Faktor Penyebab Kesulitan Belajar Matematika Pada Siswa Kelas IV di Sekolah Dasar Negeri Jawa 2 Martapura".

Adapun rumusan masalah penelitian yaitu Apa saja faktor penyebab kesulitan belajar Matematika pada siswa kelas IV di Sekolah Dasar Negeri Jawa 2 Martapura Kabupaten Banjar. Tujuan penelitian untuk mengetahui faktor penyebab kesulitan belajar dalam pembelajaran Matematika pada siswa kelas IV A dan B di Sekolah Dasar Negeri Jawa 2 Martapura Kabupaten Banjar.

\section{METODE PENELITIAN}

Metode penelitian ini adalah metode Deskriptif Kuantitatif, yaitu suatu gambaran secara sistematis, faktual dan akurat mengenai fakta dan sifat-sifat serta hubungan antara kejadian yang diselidiki.

Objek penelitian adalah faktor penyebab kesulitan belajar Matematika pada siswa kelas IV. Subjek penelitian ini siswa kelas IV A dan B Sekolah Dasar Negeri Jawa 2 Martapura Kabupaten Banjar. Populasi penelitian adalah siswa kelas IV SDN Jawa 2 Martapura yang berjumlah 57 orang, terdiri dari kelas IV A sebanyak 27 orang dan kelas IV B sebanyak 30 orang. Sampel dalam penelitian berjumlah 30 orang. Penarikan sampel menggunakan teknik random sampling sehingga, kelas IV A diambil 15 orang dan kelas IV B diambil 15 orang.

Penelitian ini menggunakan 2 alat penggali data, yaitu Angket sebagai alat penggali data utama untuk menggali data tentang kesulitan belajar siswa dalam pembelajaran Matematika dan Observasi untuk melengkapi data yang berhubungan dengan sekolah yang diteliti khususnya kelas IV dalam pembelajaran Matematika.

Data diolah dengan cara ditabulasikan dan dihitung sesuai jumlah item-item pertanyaan dari setiap jawaban responden, dengan cara (1) jawaban a bernilai 3, (2) jawaban b bernilai 2, dan (3) jawaban c bernilai 1. Data yang telah diolah kemudian dianalisis dengan menggunakan rumus prosentase berikut untuk kemudian diinterpretasikan dengan kategori seperti pada tabel 1.

$$
\mathrm{P}=\frac{f}{N} \times 100 \%
$$

Keterangan:

$\mathrm{f}=$ frekuensi yang sedang dicari persentasinya

$\mathrm{N}=$ Number of Cases (Jumlah frekuensi / banyaknya individu)

$\mathrm{P}=$ Angka persentase

( Sudijono, 2014:43)

Tabel 1. Interpretasi Data

\begin{tabular}{|c|c|c|}
\hline No & Angka Prosentase & Analisa Data \\
\hline 1 & $0-20 \%$ & Sedikit sekali \\
\hline 2 & $21-40 \%$ & Sedikit \\
\hline 3 & $41-60 \%$ & Cukup banyak \\
\hline 4 & $61-80 \%$ & Banyak \\
\hline 5 & $81-100 \%$ & Banyak sekali \\
\hline
\end{tabular}

( Sudijono, 2014:43 )

Dari penelitian di atas dapat ditarik kesimpulan sebagai berikut:

1. Jika hasil data yang diperoleh di lapangan menunjukkan angka prosentasinya $0-20 \%$ maka sedikit sekali siswa yang mengatakan tentang faktor penyebab kesulitan belajar Matematika.

2. Jika hasil di lapangan menunjukkan angka prosentasi $21-40 \%$ maka sedikit siswa yang mengatakan tentang faktor penyebab kesulitan belajar Matematika.

3. Jika hasil di lapangan menunjukkan angka prosentasi 41-60\% maka cukup banyak siswa yang mengatakan tentang faktor penyebab kesulitan belajar Matematika.

4. Jika hasil di lapangan menunjukkan angka prosentasi $61-80 \%$ maka banyak siswa yang mengatakan tentang faktor penyebab kesulitan belajar Matematika. 
5. Jika hasil di lapangan menunjukkan angka prosentasi $81-100 \%$ maka banyak sekali siswa yang mengatakan tentang faktor penyebab kesulitan belajar Matematika.

\section{HASIL DAN PEMBAHASAN}

Analisis hasil angket menggunakan frekuensi relatif, yaitu "Frekuensi dalam

\section{Tabel 2. Rekapitulasi Prosentasi Rata-Rata}

\begin{tabular}{|c|c|c|c|c|}
\hline \multirow{3}{*}{ No } & \multirow{3}{*}{ Faktor-Faktor Penyebab Kesulitan Belajar Matematika } & \multicolumn{3}{|c|}{ Alternatif Jawaban } \\
\hline & & Selalu & Kadang-Kadang & Tidak Pernah \\
\hline & & $\%$ & $\%$ & $\%$ \\
\hline & Faktor Internal yaitu kemauan, kesenangan, minat d & kesiap & siswa & \\
\hline 1. & Kemauan siswa mengerjakan soal Matematika & 11 & 23 & 66 \\
\hline & Jumlah & 11 & 23 & 66 \\
\hline & Nilai Rata-Rata & 11 & 23 & 66 \\
\hline 2. & Kesenangan siswa terhadap pembelajaran Matematika & 109 & 152 & 139 \\
\hline & Jumlah & 109 & 152 & 139 \\
\hline & Nilai Rata-Rata & 27,25 & 38 & 46,33 \\
\hline 3. & Kesulitan terhadap pembelajaran Matematika & 90 & 10 & 0 \\
\hline & Jumlah & 90 & 10 & 0 \\
\hline & Nilai Rata-Rata & 90 & 10 & $\mathbf{0}$ \\
\hline 4. & Minat terhadap Matematika & 69 & 83 & 148 \\
\hline & Jumlah & 69 & 83 & 148 \\
\hline & Nilai Rata-Rata & 23 & 27,66 & 49,33 \\
\hline 5. & Kesiapan mengikuti Pembelajaran Matematika & 26 & 40 & 34 \\
\hline & Jumlah & 26 & 40 & 34 \\
\hline & Nilai Rata-Rata & 26 & 40 & 34 \\
\hline & $\begin{array}{l}\text { Faktor Eksternal yaitu cara mengajar Guru, Metod } \\
\text { kondisi kelas }\end{array}$ & Pembel & aran, Sarana Pen & elajaran, dan \\
\hline 1. & Cara mengajar Guru & 47 & 107 & 146 \\
\hline & Jumlah & 47 & 107 & 146 \\
\hline & Nilai Rata-Rata & 15,66 & 35,66 & 48,66 \\
\hline 2. & Metode Pembelajaran & 83 & 104 & 113 \\
\hline & Jumlah & 83 & 104 & 113 \\
\hline & Nilai Rata-Rata & 27,66 & 34,66 & 37,66 \\
\hline 3. & Sarana Pembelajaran & 42 & 62 & 96 \\
\hline & Jumlah & 42 & 62 & 96 \\
\hline & Nilai Rata-Rata & 21 & 31 & 48 \\
\hline 4. & Kondisi kelas yang tenang & 127 & 40 & 30 \\
\hline & Jumlah & 127 & 40 & 33 \\
\hline & Nilai Rata-Rata & 63,5 & 20 & 16,5 \\
\hline
\end{tabular}

Berdasarkan hasil observasi aktiivitas Berdasarkan Tabel tersebut di atas maka hasil rekapitulasi dari jawaban semua angket siswa kelas IVA dan IVB tentang faktor-faktor penyebab kesulitan bentuk persentase (\%) sebagai hasil perbandingan dengan total data yang ada". (Mundir, 2013:33).

Hasil penelitian tentang Faktor Penyebab Kesulitan Belajar Matematika terlihat pada Tabel 2. 
pernah senang terhadap pembelajaran Matematika, banyak sekali $(90 \%)$ siswa mengatakan selalu kesulitan terhadap pembelajaran Matematika, cukup banyak (49,33\%) siswa mengatakan tidak pernah minat terhadap pembelajaran Matematika, sedikit (40\%) siswa mengatakan kadangkadang siap mengikuti dalam pembelajaran Matematika. Sedangkan dilihat dari faktor eksternal, cukup banyak $(48,66 \%)$ siswa mengatakan tidak pernah senang terhadap cara mengajar Guru di kelas, sedikit $(37,66 \%)$ siswa mengatakan kadang-kadang saja Guru mata pelajaran Matematika menggunakan metode pembelajaran, cukup banyak (48\%) siswa mengatakan tidak pernah mendapatkan sarana pembelajaran Matematika yang memuaskan, banyak $(63,5 \%)$ siswa yang mengatakan selalu senang terhadap kondisi kelas yang tenang.

\section{PEMBAHASAN}

Kesulitan belajar adalah suatu kondisi yang menimbulkan hambatan dalam proses belajar seseorang. Khairani (2013:187) berpendapat bahwa: "Kesulitan belajar adalah dalam keadaan dimana anak didik / siswa tidak dapat belajar sebagaimana mestinya.

Kesulitan belajar siswa yang dihadapi oleh siswa dipengaruhi oleh faktor yang terdapat dalam dirinya (internal) dan di luar dirinya (eksternal). Faktor internal adalah keadaan/ kondisi jasmani dan rohani siswa seperti, kurangnya kemampuan, motivasi/ dorongan, emosional. Faktor-faktor internal ini meliputi faktor fisiologis, psikologis, intelegensi, faktor kemauan belajar (minat dan motivasi), dan cara belajar.

Berdasarkan penelitian, banyak siswa (66\%) mengatakan tidak pernah mempunyai kemauan dalam mengerjakan soal Matematika, cukup banyak siswa $(46,33 \%)$ mengatakan tidak pernah senang terhadap pembelajaran Matematika, banyak sekali siswa (90\%) mengatakan selalu kesulitan terhadap siswa pembelajaran Matematika, cukup banyak $(49,33 \%)$ mengatakan tidak pernah minat terhadap pembelajaran Matematika, sedikit siswa (40\%) mengatakan kadangkadang siap mengikuti dalam pembelajaran Matematika.

Hasil penelitian menunjukkan gambaran bahwa siswa sangat kesulitan dalam memahami pembelajaran matematika, dan tidak senang dengan mata pelajaran matematika, ini diakibatkan kurang bervariasinya metode pembelajaran yang diberikan oleh guru matematika sehingga siswa merasa kesulitan.

Faktor fisiologis adalah faktorfaktor yang berhubungan dengan kondisi fisik individu yang dapat mempengaruhi minat dan hasil belajar siswa. Faktor ini dibedakan menjadi dua macam. Pertama, keadaan jasmani. Kondisi fisik sehat dan bugar memberikan pengaruh positif terhadap kegiatan belajar individu. Sebaliknya, kondisi fisik yang lemah atau sakit akan menghambat perolehan hasil belajar yang maksimal. Kedua, keadaan fungsi jasmani / fisiologis. Dalam proses pembelajaran, pancaindra merupakan pintu masuk bagi segala informasi yang diterima dan ditangkap oleh manusia, sehingga manusia dapat mengenal dunia luar. Pancaindra yang memiliki peran besar dalam aktivitas belajar adalah mata dan telinga. Oleh karena itu, guru maupun siswa perlu menjaga pancaindra dengan baik dan mengkonsumsi makanan yang bergizi.

Faktor psikologi adalah keadaan psikologis seseorang yang dapat mempengaruhi proses belajar seperti kecerdasan siswa, motivasi, minat, sikap, dan bakat. Semakin tinggi tingkat intelegensi seorang individu, semakin besar peluang individu tersebut meraih sukses dalam belajar. Sebaliknya, semakin rendah tingkat intelegensi individu, semakin sulit individu itu mencapai kesuksesan belajar.

Faktor intelegensi sebenarnya bukan persoalan kualitas otak saja, melainkan 
kualitas organ-organ tubuh lainnya. Akan tetapi, memang harus diakui bahwa peran otak dalam hubungannya denagn intelegensi manusia lebih menonjol daripada peran organ-organ tubuh lainnya. Tingkat kecerdasan atau intelegensi siswa tak dapat diragukan lagi, sangat menentukan tingkat keberhasilan siswa.

Minat adalah kecenderungan dan kegairahan yang tinggi atau keinginan yang besar terhadap sesuatu (Baharudin \& Wahyuni, 2012:24). Minat mempengaruhi aktivitas belajar siswa, sama halnya dengan kecerdasan dan motivasi. Jika seseorang tidak memiliki minat untuk belajar, ia tidak akan memiliki semangat belajar. Berbeda dengan bakat, minat bersumber dari hasil pengenalan lingkungan, atau hasil berinteraksi dan belajar dengan lingkungannya. tanpa adanya minat maka segala kegiatan yang dilakukan menjadi kurang efektif dan efesien sehingga tidak dapat mencapai prestasi yang baik.

Motivasi adalah proses internal yang kompleks yang tak bisa diamati secara langsung, melainkan bisa dipahami melalui kerasnya seseorang dalam mengerjakan sesuatu (Makmun, 2013:176). Motivasi mempunyai 3 aspek, yaitu: Keadaan terdorong dalam diri organisme, perilaku yang timbul dan terarah karena arah keadaan ini, dan tujuan perilaku tersebut.

Cara belajar efektif adalah cara belajar yang sesuai dengan kondisi personal pembelajar, baik dari segi metode, penggunaan tempat, ataupun penggunaan waktu. Sedangkan belajar efesien adalah cara belajar yang meminimalkan usaha tetapi mendapatkan hasil yang maksimal. Yang diminimalkan disini juga berupa waktu, tempat, sarana dan prasarana belajar, membuat review materi, mengembangkan materi, mengadakan diskusi, dan membuat kesimpulan.

Faktor Eksternal adalah Faktor yang berasal luar diri individu namun dapat mempengaruhi hasil belajar individu, yaitu faktor Lingkungan seperti keluarga, sekolah, masyarakat, dan lingkungan sekitar.

Dilihat dari faktor eksternal, penelitian ini menunjukkan bahwa cukup banyak siswa $(48,66 \%)$ mengatakan tidak pernah senang terhadap cara mengajar Guru di kelas, sedikit siswa $(37,66 \%)$ mengatakan kadang-kadang saja Guru mata pelajaran Matematika menggunakan metode pembelajaran, cukup banyak siswa (48\%) mengatakan tidak pernah mendapatkan sarana pembelajaran Matematika yang memuaskan, banyak siswa $(63,5 \%)$ yang mengatakan selalu senang terhadap kondisi kelas yang tenang.

Keluarga adalah kelompok sosial pertama bagi manusia, maka pusat pendidikan pertama dan yang paling utama ada pada Keluarga (Wahy, 2012), Ki Hajar Dewantara menguraikan peran penting pendidikan keluarga, sebagai salah satu faktor yang dapat mempengaruhi kegiatan belajar, dan juga bisa menyebabkan kesulitan belajar. Faktor ini antara lain: cara mendidik anak, hubungan orang tua dan anak, bimbingan dari orang tua (Labaso, 2018).

Faktor sekolah seperti guru, administrasi, dan teman-teman sekelas dapat mempengaruhi proses belajar seorang siswa. Hubungan yang harmonis antara ketiganya dapat menjadi motivasi bagi siswa untuk belajar lebih baik disekolah. Perilaku yang simpatik dan dapat menjadi teladan seorang guru dapat menjadi pendorong bagi siswa untuk belajar (Baharudin \& Wahyuni, 26:2012).

Kondisi lingkungan masyarakat tempat tinggal akan mempengaruhi belajar siswa seperti Lingkungan kumuh, banyak pengangguran dan anak terlantar sehingga siswa kesulitan ketika membutuhkan teman diskusi belajar srdiskusi. Faktor lingkungan lainnya antara lain seperti tempat tinggal/rumah, waktu belajar, gedung/bangunan sekolah, alat-alat belajar, dan keadaan cuaca. 
Konsep Matematika berdasarkan pemahaman Hiebert dan Carpenter (Hariwijaya, 2009) menjelaskan bahwa: "Pemahaman memudahkan terjadinya transfer. Siswa dikatakan memahami bila mereka bisa mengkontruksi makna dari pesan-pesan pembelajaran, baik yang bersifat lisan, tulisan ataupun grafis, yang disampaikan melalui pengajaran, buku, atau layar komputer". Jika hanya memberikan keterampilan saja tanpa dipahami, akibatnya siswa akan mengalami kesulitan belajar materi selanjutnya, sehingga siswa akan menganggap Matematika merupakan pelajaran yang sulit. Pemahaman dalam pembelajaran Matematika sudah seharusnya tertanam kepada setiap siswa oleh guru sebagai pendidik. Karena tanpa pemahaman, siswa tidak bisa mengaplikasikan prosedur, konsep, ataupun proses.

Adapun tujuan dari pengajaran Matematika adalah: Mempersiapkan siswa agar sanggup menghadapi perubahan keadaan, perubahan pola pikir dalam kehidupan sehari-hari dan kehidupan dunia yang selalu berkembang agar dapat mempelajari berbagai ilmu pengetahuan serta mampu menyelesaiakan berbagai macam pemecahan masalah. Berdasarkan hal tersebut, hendaknya guru matematika mengkondisikan bagaimana pembelajaran matematika yang sekiranya disukai oleh siswa agar tidak terjadi kebosanan sehingga dapat mengurangi kesulitan pada mata pelajaran matematika.

\section{PENUTUP}

Berdasarkan hasil penelitian yang berjudul "Faktor Penyebab Kesulitan Belajar Matematika Pada Siswa Kelas IV Di Sekolah Dasar Negeri Jawa 2 Martapura Kabupaten Banjar". Dari data tersebut dapat disimpulkan: Faktor-faktor penyebab kesulitan belajar Matematika dilihat dari faktor internal, banyak siswa mengatakan tidak pernah mempunyai kemauan dalam mengerjakan soal Matematika, cukup banyak siswa mengatakan tidak pernah senang terhadap pembelajaran Matematika, banyak sekali siswa mengatakan selalu kesulitan terhadap pembelajaran Matematika, cukup banyak siswa mengatakan tidak pernah minat terhadap pembelajaran Matematika, sedikit siswa mengatakan kadang-kadang siap mengikuti dalam pembelajaran Matematika. Sedangkan dilihat dari faktor eksternal, cukup banyak siswa mengatakan tidak pernah senang terhadap cara mengajar Guru di kelas, sedikit siswa mengatakan kadang-kadang saja Guru mata pelajaran Matematika menggunakan metode pembelajaran, cukup banyak siswa mengatakan tidak pernah mendapatkan sarana pembelajaran Matematika yang memuaskan, banyak siswa yang mengatakan selalu senang terhadap kondisi kelas yang tenang.

Adapun saran yang dapat diberikan yaitu : (1) Kepada guru mata pelajaran Matematika hendaknya terus meningkatkan teknik dan kreativitas dalam mengajar, serta terus memberikan bimbingan dan memotivasi para siswa dalam belajar. (2) Kepada Kepala Sekolah hendaknya terus memperhatikan faktorfaktor penyebab kesulitan belajar pada siswa dan tetap memperhatikan kinerja guru, baik dalam mendidik maupun mengajar. Selain itu juga memperhatikan kelengkapan fasilitas dan sarana belajar untuk menunjang kelancaran pendidikan. (3) Kepada Siswa hendaknya belajar lebih giat lagi dan menyadari betapa pentingnya pelajaran Matematika untuk kemudian hari, jangan merasa cukup dengan yang telah ada, benahi diri untuk mengurangi kesulitan-kesulitan yang ada.

\section{DAFTAR PUSTAKA}

Andri, Olenggius Jiran Dores, dan Anastasia Helina. (2020). Analisis Faktor Penyebab Kesulitan Belajar Matematika pada siswa SDN 01 Nanga Kantuk. J-PiMat: Jurnal Pendidikan Matematika. 2(1):158-167 


\section{May 2020, DOI: $10.31932 / \mathrm{j}-$ pimat.v2i1.688}

Arikunto, Suharsimi, (2010). Prosedur Penelitian Suatu Pendekatan Praktek. Jakarta. PT. Rineka Cipta.

Baharuddin H, (2017). Pendidikan dan Psikologi Perkembangan. Jogyakarta: PT Ar Ruzz Media.

Baharudin \& Esa Nur Wahyuni, (2012). Teori Belajar dan Pembelajaran. Jogjakarta: PT Ar Ruzz Media.

Dimayati, dan Mudjiono. (2017). Belajar dan Pembelajaran. Jakarta: PT Rineka Cipta.

Djaelani, M Bisri. (2011). Psikologi Pendidikan. Penerbit CV Arya Duta.

Hariwijaya. (2009). Meningkatkan Kecerdasan Matematika. PT Tugu Publisher.

Khairani, Makmun. (2017). Psikologi Belajar. Yogyakarta. Penerbit Aswaja Pressindo.

Khairani, Makmun. (2013). Psikologi Umum. Yogyakarta. Penerbit Aswaja Pressindo.

Labaso, Syahrial. (2018). Konsep Pendidikan Keluarga Dalam Perspektif Al-Qura'an dan Hadis. Jurnal Pendidikan Agama Islam Vol XV, No.1, Juni 2018. DOI : 10.14421/jpai.2018.151-04

Mabruroh, U., Sunarsih, D.., \& Mumpuni, A. (2020). Analisis Kesulitan Belajar Muatan Matematika Kelas IV SD Tahfidzul Qur'an Darul Abror. Jurnal Ilmiah KONTEKSTUAL, 2(01), 58-68. https://doi.org/10.46772/kontekstual. $\underline{\mathrm{v} 2 \mathrm{i} 01.250}$
Mundir. (2013). Statsitika Pendidikan. Yogyakarta: Pustaka Pelajar.

Nazir, Moh. (2014). Metode Penelitian. Ghalia Indonesia.

Nurjannah, N., Danial, D., \& Fitriani, F. (2019). Diagnostik Kesulitan Belajar Matematika Siswa Sekolah Dasar Pada Materi Operasi Hitung Bilangan Bulat Negatif. Didaktika : Jurnal Kependidikan, 13(1), 68-79. doi:https://doi.org/10.30863/didaktika .v13i1.340.

Sanjaya, Wina. (2015). Penelitian Pendidikan: Metode, Pendekatan, dan Jenis. Jakarta: Kencana Prenada Media Group. ISBN: 6232182197; 9786232182196.

Sudijono, Anas. (2014). Pengantar Statistik Pendidikan. Jakarta: PT Raja Grafindo Persada.

Sukirman. (2011). Peranan Bimbingan Guru Dan Motivasi Belajar Dalam Rangka Meningkatkan Prestasi Belajar Peserta Didik SMA Negeri 1 Metro Tahun 2010. GUIDENA: Jurnal Ilmu Pendidikan, Psikologi, Bimbingan dan Konseling. 1. 23. DOI: $10.24127 / \mathrm{gdn} . v 1 \mathrm{i} 1.349$

Sumantri, Mulyani (2014) Perkembangan Peserta Didik. In: Pertumbuhan dan Perkembangan Anak. Universitas Terbuka, Jakarta, pp. 1-52. ISBN 9789790116320

Surya Sultan \& Hariwijaya, (2009). Adventures in Math Tes IQ Matematika. Yogyakarta: Tugu Publisher.

Surahman, Hasniah, dan Jafar Ahiri. (2020). Identifikasi Faktor Penyebab Kesulitan Belajar Siswa Pada Mata Pelajaran Ekonomi Kelas X IIS di SMA Negeri 1 Maginti Kabupaten 
MUna Barat. Jurnal Online Program Studi Pendidikan Ekonomi.

Tirtaraharja, Umar., dan S.L. Sulo La., (2015). Pengantar pendidikan (2). Jakarta: Rineka Cipta. ISBN: 979628 8321
Wahy, Hasbi. (2012). Keluarga Sebagai Basis Pendidikan Pertama dan Utama. Jurnal Ilmiah Didaktika Vol XII No.2, 245-258.

https://media.neliti.com/media/public ations/81957-ID-keluarga-sebagaibasis-pendidikan-pertam.pdf 